\title{
Analisis Temperatur terhadap Konversi Tepung Jagung ke Molases pada Tahap sakarifikasi
}

\author{
Sutrisnawati Mehora*1, Surya Ningsih ${ }^{2}$ \\ ${ }^{1,2}$ Universitas Sembilanbelas November Kolaka \\ e-mail: ${ }^{* 1}$ mehora2017@ gmail.com, ${ }^{2}$ sningsih993@ gmail.com
}

\begin{abstract}
Abstrak
Temperatur sangat mempengaruhi dalam menghidrolisis tepung jagung ke molases dilakukan tiga tahap yakni, gelatinase, likuifikasi, dan sakarifikasi. Metode penelitian yang digunakan yaitu metode eksperimen yang dilakukan di laboratorium. Hasil penelitian ini diperoleh nilai kadar molases, massa molases, dan nilai efisiensi. Pada temperatur (40-45) ${ }^{\circ} \mathrm{C}$ kadar molases yang dihasilkan yakni 8,8\%, massa molases $19,33 \mathrm{gr}$, efisiensi $64 \%$. Pada temperatur (45-50) ${ }^{\circ} \mathrm{C}$ kadar molases yang dihasilkan yakni 11,6\%, massa molases 25,69 gr, dan efisiensi $86 \%$. Pada temperatur (50-55) ${ }^{\circ} \mathrm{C}$ kadar molases yang dihasilkan meningkat menjadi $13 \%$, massa molases 26,27 gr, dan efisiensi 88\%. Pada temperatur (55-60) ${ }^{\circ} \mathrm{C}$ kadar molases lebih meningkat menjadi 14,6\%, massa molases 28,86 gr dan efisiensi $90 \%$.. Ini artinya semakin tinggi temperatur maka kadar molases juga akan semakin bertambah. Pada temperatur rentang (40-45) ${ }^{\circ} \mathrm{C}$ hanya sebagian kecil molekul yang memiliki energi aktivasi yang cukup untuk bertumbukan menghasilkan reaksi, sehingga tepung jagung yang berhasil terhidrolisis lebih sedikit, sebaliknya pada temperatur (55-60) ${ }^{\circ} \mathrm{C}$ energi kinetik molekul naik sehingga menyebabkan peningkatan laju reaksi. Pada temperatur tersebut adalah temperatur optimum enzim gluko amilase bekerja. Hal ini bersesuaian dengan distribusi Maxwell-Boltzmann yang menyatakan bahwa reaksi akan semakin cepat dengan adanya pertambahan temperatur..
\end{abstract}

Kata kunci: Tepung jagung, molases, temperatur

\section{PENDAHULUAN}

Tepung jagung adalah tepung yang diproduksi dari jagung pipil kering dengan cara menggiling halus bagian endosperm jagung yang mengandung pati sekitar $86,89 \%$. Penggilingan biji jagung ke dalam bentuk tepung merupakan suatu proses pemisahan kulit, endosperm, Lembaga dan tip cap. Endosperm merupakan bagian dari biji jagung yang digiling menjadi tepung jagung dan memiliki kadar karbohidrat yang tinggi. Kulit yang mengandung serat tinggi harus dipisahkan karena dapat membuat tepung bertekstur kasar. Selain itu, Lembaga yang merupakan bagian biji jagung dengan kandungan lemak tertinggi juga harus dipisahkan agar tepung tidak menjadi tengik. Begitu pula dengan tip cap yang harus dipisahkan sebelum penepungan agar tidak terdapat butir-butir hitam pada tepung olahan (Johnson, 1991).

Komponen terbesar dalam tepung jagung adalah pati. Dari penelitian Juniawati (203), tepung jagung memiliki kadar pati sebesar 68,2\%. Dari kandungan pati yang dimiliki Tepung jagung berpotensi sebagai bahan baku industry minuman dan industry kimia. Salah satu nya adalah bahan baku dalam pembuatan molases. Molases adalah sumber energi yang memiliki kandungan gula didalamnya yang berbentuk cair. Molases memiliki kandungan gula yang tinggi, sehingga banyak industry menggunakan molases sebagai bahan baku yang dapat difungsikan sebagai alternative bahan baku etanol (G,C, Goncalves et al. 2016). Molasses dari tepung jagung dikonversi dengan menghidrolisis tepung jagung. Dalam menghidrolisis, temperatur sangat mempengaruhi kosentrasi molasses.

Kenaikan temperatur menyebabkan energi kinetik molekul meningkat. Peningkatan energy yang cukup bagi molekul reaktan akan meningkatkan laju reaksi sehingga semakin tinggi temperatur konversi yang diperoleh akan semakin tinggi pada temperature yang tidak melebihi temperature optimum enzim bekerja. 
https://jurnal.unsulbar.ac.id/index.php/saintifik

Dalam menghidrolisis tepung jagung dilakukan dengan tiga tahap yakni, gelatinasi, likuifikasi, dan sakarifikasi.

Sifat pati tidak larut dalam air, namun bila suspensi pati dipanaskan akan terjadi gelatinasi setelah mencapai suhu tertentu (suhu gelatinasi). Hal ini disebabkan oleh pemanasan energi kinetic molekul-molekul air yang menjadi lebih kuat dari pada daya tarik menarik antara molekul pati dalam granula, sehingga air dapat masuk ke dalam pati tersebut, dan pati akan mengembang. Enzim penghidrolisis pati yang digunakan terdiri atas alfa-amilase dan glukoamilase.Enzim merupakan katalisator yang mempercepat reaksi biologis tanpa ikut bereaksi (Edra, 2017).

\section{METODE PENELITIAN}

Penelitian dilakukan dengan menggunakan metode eksperimen, dan dilaksanakan di Laboratorium IPA Terpadu Universitas Sembilanbelas November Kolaka. Bahan yang digunakan : tepung Jagung (Maizena), Air, alfa amilase,dan gluko amilase. Alat yang digunakan : Wadah berfungsi untuk tempat sampel, Termometer digital (LH 666 190, DIGITAL TEMPERATURE MESSAGE RAET) berfungsi untuk mengukur temperatur pada sampel, Hot Plate CS. 76083V berfungsi untuk memanaskan sampel, Power supply (LH 52242 STELLTRA FOEINPH VARIABLE TRANSFORMER, SINGLE-PHASEA) berfungsi untuk menyalurkan energy listrik yang diperlukan, Timbangan Digital berfungsi untuk menimbang, Brix Meter (AH 90ATCI, JAPAN) berfungsi untuk mengukur kosentrasi molasses, Sarung tangan berfungsi untuk melindungi tangan pada saat memanaskan sampel, Tissue berfungsi untuk membersihkan alat-alat yang telah digunakan.

Adapun Langkah - langkah eksperimen adalah sebagai berikut: Semua alat dan bahan disiapkan, tepung jagung ditimbang kemudian dicampur air, diaduk pada frekuensi $2050 \mathrm{rpm}$ dan dipanaskan hingga temperatur $90{ }^{\circ} \mathrm{C}$ (sebelum dipanaskan diuji kadar sampel dengan menggunakan Brix-meter). Setelah temperature mencapai $90{ }^{\circ} \mathrm{C}$, ditambahkan enzim alfa-amilase sesuai dengn ktentuan kedalam sampel kemudian dipertahankan pada temperature $85{ }^{\circ} \mathrm{C}-90{ }^{\circ} \mathrm{C}$ selama satu jam (proses likuifikasi), Selanjutnya sampel didinginkan hingga suhu $60^{\circ} \mathrm{C}$, kemudian ditambahkan enzim gloko-amilase sesuai dengan ketentuan, tetap diaduk selama 3 jam dan dipertahankan pada temperature $55{ }^{\circ} \mathrm{C}-60{ }^{\circ} \mathrm{C}$ (proses sakarifikasi). Kadar molasses sampel diuji tiap 30 menit selama 3 jam. Langkah 1-6 diulangi deengan variasi temperature $\left(50{ }^{\circ} \mathrm{C}\right.$ $55^{\circ} \mathrm{C}, 45^{\circ} \mathrm{C}-50^{\circ} \mathrm{C}, 40^{\circ} \mathrm{C}-45^{\circ} \mathrm{C}$ ). Temperatur dianalisis terhadap konversi tepung menjadi molases pada tahap sakarifikasi.

\section{HASIL DAN PEMBAHASAN}

Pada penelitian ini bahan baku yang digunakan adalah tepung jagung sebanyak 30 gram setiap selang waktu yang telah ditentukan. Tepung dikonversi menjadi molases melalui proses gelatinasi, likuifikasi, dan sakarifikasi. Pada tahap likuifikasi yaitu pencampuran tepung dengan air secara merata, kemudian dipanaskan hingga menjadi bubur, penambahan enzim (alfa-amilase) sebanyak 0,021 gram pada temperatur $90^{\circ} \mathrm{C}$. Untuk penambahan alfa-amilase dilakukan dengan cara perhitungan yakni 0,1 dikalikan dengan kandungan pati pada tepung jagung kemudian dikalikan dengan banyaknya tepung jagung yang digunakan. Pada pemanasan bubur, tepung akan mengalami gelatinasi (mengental seperti jel) seiring dengan kenaikan temperatur, sampai temperatur optimum enzim bekerja memecahkan struktur tepung secara kimiawi menjadi gula kompleks (dextrin).

Proses likuifikasi selesai ditandai dengan parameter dimana bubur yang diproses menjadi lebih cair seperti sup. Pada tahap sakarifikasi yaitu pendinginan bubur sampai temperatur optimum enzim sakarifikasi bekerja, penambahan enzim (gluko-amilase) sebanyak 0,02 gram, serta diberi perlakuan yaitu variasi temperatur. Untuk penambahan gluko amilase dilakukan dengan cara perhitungan yakni, 0,09 dikalikan dengan kandungan pati pada tepung jagung kemudian dikalikan dengan banyaknya tepung jagung yang digunakan. Dalam mengkonversi dan menganalisis temperatur pada tepung jagung ke molases dilakukan pada kecepatan pengadukan konstan yaitu $2050 \mathrm{rpm}$, waktu hidrolisis kurang lebih 5 jam, dan temperatur tahap sakarifikasi yakni: $(40-45){ }^{\circ} \mathrm{C},(45-50){ }^{\circ} \mathrm{C},(50-55){ }^{\circ} \mathrm{C},(55-60){ }^{\circ} \mathrm{C}$. Alasan pemilihan selang temperatur $40{ }^{\circ} \mathrm{C}-$ 
$60{ }^{\circ} \mathrm{C}$ didasarkan pada kondisi optimum gluko amilas bekerja. Jika temperatur pada tahap sakarifikasi kurang dari $40{ }^{\circ} \mathrm{C}$ gluko amilase tidak dapat bekerja dengan baik. Sebaliknya, jika di atas temperatur $60{ }^{\circ} \mathrm{C}$ maka gluko amilase akan rusak. Hasilnya dapat dilihat dari tabel sebagai berikut:

Pada penelitian ini bahan baku yang digunakan adalah tepung jagung sebanyak 30 gram. Tepung dikonversi menjadi molases melalui proses gelatinasi, likuifikasi, dan sakarifikasi. Pada tahap likuifikasi yaitu pencampuran tepung dengan air secara merata, kemudian dipanaskan hingga menjadi bubur, penambahan enzim (alfa-amilase) sebanyak 0,021 gram pada temperatur $90{ }^{\circ} \mathrm{C}$. Untuk penambahan alfa-amilase dilakukan dengan cara perhitungan yakni 0,1 dikalikan dengan kandungan pati pada tepung jagung kemudian dikalikan dengan banyaknya tepung jagung yang digunakan.

Pada pemanasan bubur, tepung akan mengalami glatinasi (mengental seperti jel) seiring dengan knaikan temperatur, sampai temperatur optimum enzim bekrja memcahkan struktur tepung secara kimiawi menjadi gula kompleks (dextrin). Proses likuifikasi selesai ditandai dengan parameter dimana bubur yang diproses menjadi lebih cair seperti sup. Pada tahap sakarifikasi yaitu pendinginan bubur sampai temperatur optimum enzin sakarifikasi bekerja, penambahan enzim (gluko-amilase) sebanyak 0,02 gram, serta diberi prlakuan yaitu variasi temperatur. Untuk penambahan gluko amilase dilakukan dengan cara perhitungan yakni, 0,09 dikalikan dengan kandungan pati pada tepung jagung kemudian dikalikan dengan banyaknya tepung jagung yang digunakan.

Dalam mengkonversi dan menganalisis temperatur pada tepung jagung ke molases dilakukan pada kecepatan pengadukan $2050 \mathrm{rpm}$, waktu hidrolisis kurang lebih $5 \mathrm{jam}$, dan temperatur tahap sakarifikasi yakni: (40-45) ${ }^{\circ} \mathrm{C},(45-50){ }^{\circ} \mathrm{C},(50-55){ }^{\circ} \mathrm{C},(55-60){ }^{\circ} \mathrm{C}$. Alasan pemilihan selang temperatur $40{ }^{\circ} \mathrm{C}-60{ }^{\circ} \mathrm{C}$ didasarkan pada kondisi optimum gluko amilas bekerja. Jika temperatur pada tahap sakarifikasi kurang dari $40{ }^{\circ} \mathrm{C}$ gluko amilase tidak dapat bekerja dengan baik. Sebaliknya, jika di atas temperatur $60{ }^{\circ} \mathrm{C}$ maka gluko amilase akan rusak. Hasilnya dapat dilihat dari tabel sebagai berikut:

Tabel 1.Data hasil hidrolisis pada temperatur rentang $55^{\circ} \mathrm{C}-60{ }^{\circ} \mathrm{C}$ selama kurang lebih 5 jam

\begin{tabular}{|c|c|c|c|c|c|c|c|c|}
\hline No & $\begin{array}{c}\mathrm{T} \\
\left({ }^{\circ} \mathrm{C}\right)\end{array}$ & $\begin{array}{c}\mathrm{t} \\
\text { (menit) }\end{array}$ & $\begin{array}{c}\text { Kadar } \\
\text { Molases (\%) }\end{array}$ & $\begin{array}{l}\text { Massa } \\
\text { total (g) }\end{array}$ & $\begin{array}{c}\text { Massa } \\
\text { sampel (g) }\end{array}$ & $\begin{array}{c}\text { Massa } \\
\text { Molases (g) }\end{array}$ & $\begin{array}{l}\eta \\
(\%)\end{array}$ & Ket. \\
\hline 1 & 30.7 & 0 & 0 & 451.5 & 330 & 0 & 0 & \multirow{2}{*}{$\begin{array}{c}\text { Proses } \\
\text { Gelatinasi }\end{array}$} \\
\hline 2 & 90 & 27 & 6 & 420.5 & 299 & 17.94 & 60 & \\
\hline 3 & $85-90$ & 87 & 11.2 & 339 & 217.5 & 24.36 & 81 & \multirow{2}{*}{$\begin{array}{c}\text { Proses } \\
\text { likuifikasi }\end{array}$} \\
\hline 4 & 60 & 111 & 11.4 & 338.9 & 217.4 & 24.8 & 83 & \\
\hline 5 & $55-60$ & 141 & 12 & 332 & 210.5 & 25.26 & 84 & \multirow{6}{*}{$\begin{array}{c}\text { Proses } \\
\text { sakarifikasi }\end{array}$} \\
\hline 6 & $55-60$ & 171 & 12.6 & 324.5 & 203 & 25.58 & 85 & \\
\hline 7 & $55-60$ & 201 & 13 & 320.5 & 199 & 25.87 & 86 & \\
\hline 8 & $55-60$ & 231 & 13.4 & 315 & 193.5 & 25.93 & 87 & \\
\hline 9 & $55-60$ & 271 & 14 & 310 & 188.5 & 26.39 & 88 & \\
\hline 10 & $55-60$ & 301 & 14.6 & 299.5 & 184 & 28.86 & 90 & \\
\hline
\end{tabular}

Tabel 2.Data hasil hidrolisis pada temperatur rentang $50{ }^{\circ} \mathrm{C}-55^{\circ} \mathrm{C}$ selama kurang lebih 5 jam

\begin{tabular}{|c|c|c|c|c|c|c|c|c|}
\hline No & $\begin{array}{c}\mathrm{T} \\
\left({ }^{\circ} \mathrm{C}\right)\end{array}$ & $\begin{array}{c}\mathrm{t} \\
\text { (menit) }\end{array}$ & $\begin{array}{c}\text { Kadar } \\
\text { Molases (\%) }\end{array}$ & $\begin{array}{l}\text { Massa } \\
\text { total (g) }\end{array}$ & $\begin{array}{c}\text { Massa } \\
\text { sampel (g) }\end{array}$ & $\begin{array}{c}\text { Massa } \\
\text { Molases (g) }\end{array}$ & $\begin{array}{c}\eta \\
(\%)\end{array}$ & Ket. \\
\hline 1 & 27.3 & 0 & 0 & 451.5 & 330 & 0 & 0 & \multirow{2}{*}{$\begin{array}{c}\text { Proses } \\
\text { Gelatinasi }\end{array}$} \\
\hline 2 & 90 & 25 & 4 & 427 & 305.5 & 12.2 & 41 & \\
\hline 3 & $85-90$ & 85 & 10.8 & 343 & 221.5 & 23.92 & 80 & \multirow{2}{*}{$\begin{array}{c}\text { Proses } \\
\text { likuifikasi }\end{array}$} \\
\hline 4 & 55 & 123 & 11 & 348.5 & 227 & 24.97 & 83 & \\
\hline 5 & $50-55$ & 153 & 11.6 & 338 & 216.5 & 25.11 & 84 & \multirow{2}{*}{$\begin{array}{c}\text { Proses } \\
\text { sakarifikasi }\end{array}$} \\
\hline 6 & $50-55$ & 183 & 12 & 334 & 212.5 & 25.5 & 85 & \\
\hline
\end{tabular}


https://jurnal.unsulbar.ac.id/index.php/saintifik

\begin{tabular}{|c|c|c|c|c|c|c|c|}
7 & $50-55$ & 213 & 12.4 & 329.5 & 208 & 25.79 & 86 \\
\hline 8 & $50-55$ & 243 & 12.6 & 327.3 & 205.8 & 25.93 & 86 \\
\hline 9 & $50-55$ & 273 & 12.8 & 325 & 203.5 & 26.05 & 87 \\
\hline 10 & $50-55$ & 303 & 13 & 323.6 & 204.8 & 26.27 & 88 \\
\hline
\end{tabular}

Tabel 3.Data hasil hidrolisis pada temperatur rentang $45^{\circ} \mathrm{C}-50^{\circ} \mathrm{C}$ selama kurang lebih 5 jam

\begin{tabular}{|c|c|c|c|c|c|c|c|c|}
\hline No & $\begin{array}{c}\mathrm{T} \\
\left({ }^{\circ} \mathrm{C}\right)\end{array}$ & $\begin{array}{c}\mathrm{t} \\
\text { (menit) }\end{array}$ & $\begin{array}{c}\text { Kadar } \\
\text { Molases }(\%)\end{array}$ & $\begin{array}{c}\text { Massa } \\
\text { total }(\mathrm{g})\end{array}$ & $\begin{array}{c}\text { Massa } \\
\text { sampel (g) }\end{array}$ & $\begin{array}{c}\text { Massa } \\
\text { Molases (g) }\end{array}$ & $\begin{array}{c}\eta \\
(\%)\end{array}$ & Ket. \\
\hline 1 & 31.7 & 0 & 0 & 451.5 & 330 & 0 & 0 & \multirow{2}{*}{$\begin{array}{c}\text { Proses } \\
\text { gelatinase }\end{array}$} \\
\hline 2 & 90 & 32 & 5.4 & 421.5 & 300 & 16.2 & 54 & \\
\hline 3 & $85-90$ & 92 & 10 & 371.3 & 249.8 & 24.98 & 83 & \multirow{2}{*}{$\begin{array}{c}\text { Proses } \\
\text { likuifikasi }\end{array}$} \\
\hline 4 & 50 & 130 & 10.4 & 363.2 & 241.5 & 25.14 & 84 & \\
\hline 5 & $45-50$ & 160 & 10.6 & 359.5 & 338 & 25.23 & 84 & \multirow{6}{*}{$\begin{array}{c}\text { Proses } \\
\text { sakarifikasi }\end{array}$} \\
\hline 6 & $45-50$ & 190 & 10.8 & 356 & 234.5 & 25.33 & 84 & \\
\hline 7 & $45-50$ & 220 & 11 & 352 & 230.5 & 25.35 & 85 & \\
\hline 8 & $45-50$ & 250 & 11.2 & 349.2 & 227.7 & 25.5 & 85 & \\
\hline 9 & $45-50$ & 280 & 11.4 & 346 & 224.5 & 25.6 & 85 & \\
\hline 10 & $45-50$ & 310 & 11.6 & 343 & 221.5 & 25.69 & 86 & \\
\hline
\end{tabular}

Tabel 4. Data hasil hidrolisis pada temperatur rentang $40{ }^{\circ} \mathrm{C}-45^{\circ} \mathrm{C}$ selama kurang lebih 5 jam

\begin{tabular}{|c|c|c|c|c|c|c|c|c|}
\hline No & $\begin{array}{c}\mathrm{T} \\
\left({ }^{\circ} \mathrm{C}\right)\end{array}$ & $\begin{array}{c}\mathrm{t} \\
\text { (menit) }\end{array}$ & $\begin{array}{c}\text { Kadar } \\
\text { Molases }(\%)\end{array}$ & $\begin{array}{l}\text { Massa } \\
\text { total (g) }\end{array}$ & $\begin{array}{c}\text { Massa } \\
\text { sampel (g) }\end{array}$ & $\begin{array}{c}\text { Massa } \\
\text { Molases (g) }\end{array}$ & $\eta(\%)$ & Ket. \\
\hline 1 & 27.6 & 0 & 0 & 451.5 & 330 & 0 & 0 & \multirow{2}{*}{$\begin{array}{c}\text { Proses } \\
\text { gelatinase }\end{array}$} \\
\hline 2 & 90 & 24 & 5 & 423.5 & 302 & 15.1 & 50 & \\
\hline 3 & $85-90$ & 84 & 8 & 373.3 & 251.8 & 20.14 & 67 & \multirow{2}{*}{$\begin{array}{c}\text { Proses } \\
\text { likuifikasi }\end{array}$} \\
\hline 4 & 45 & 136 & 8.2 & 369 & 247.5 & 20.29 & 68 & \\
\hline 5 & $40-45$ & 166 & 8.6 & 359.8 & 238.3 & 20.49 & 68 & \multirow{6}{*}{$\begin{array}{c}\text { Proses } \\
\text { sakarifikasi }\end{array}$} \\
\hline 6 & $40-45$ & 196 & 8.8 & 355 & 233.5 & 20.55 & 68 & \\
\hline 7 & $40-45$ & 226 & 8.8 & 352.8 & 231.3 & 20.35 & 68 & \\
\hline 8 & $40-45$ & 256 & 8.8 & 349 & 227.5 & 20.02 & 67 & \\
\hline 9 & $40-45$ & 286 & 8.8 & 344 & 222.5 & 19.58 & 65 & \\
\hline 10 & $40-45$ & 316 & 8.8 & 341.2 & 219.7 & 19.33 & 64 & \\
\hline
\end{tabular}

Dari hasil konversi diperoleh massa molases, kadar molases, dan efisiensi molases. Namun, pada pembahasan hanya dibahas pengaruh temperatur terhadap konversi tepung jagung ke molases pada tahap sakarifikasi. Massa molases didapatkan melalui perhitungan yaitu kadar molases dalam satuan persen dikalikan dengan massa sampel dalam satuan gram. Nilai efisiensi didapatkan melalui perhitungan yaitu massa molases dibagi dengan massa bahan baku yang digunakan dikali seratus persen. Efisiensi menunjukkan perbandingan hasil yang diperoleh terhadap bahan baku untuk mengetahui hasil terbaik yang diperoleh dari jumlah bahan baku yang sama pada temperatur berbeda.

Pada penelitian ini tepung jagung dihidrolisis dengan menggunakan dua teknik, yaitu teknik fisika dan teknik kimia. Pada teknik fisika tepung dikonversi pada kondisi temperatur awal sampai temperatur $90{ }^{\circ} \mathrm{C}$ (gelatinasi) kemudian dipertahankan selang temperatur (85-90) ${ }^{\circ} \mathrm{C}$ (likuifikasi) kemudian didinginkan pada masing-masing selang temperatur yang telah ditentukan yaitu: $(40-45){ }^{\circ} \mathrm{C},(45-50){ }^{\circ} \mathrm{C},(50-55){ }^{\circ} \mathrm{C},(55-60){ }^{\circ} \mathrm{C}$ dengan cara diaduk selama 3 jam. Teknik kimia yaitu tepung dihidrolisis dengan bantuan enzim dengan kondisi keasaman tertentu. Pada penelitian ini enzim yang digunakan adalah enzim $\alpha$-amilase dan gluko-amilase. 
Berdasarkan tabel 1 dapat dilihat bahwa kadar molases pada brix meter dapat terbaca pada temperatur $90{ }^{\circ} \mathrm{C}$. Tmperatur $90{ }^{\circ} \mathrm{C}$ adalah temperatur optimum enzim ( $\alpha$-amilase) bekerja memecahkan struktur tepung menjadi gula kompleks. Kenaikan temperatur menyebabkan energi kinetik molekul naik. Peningkatan enegi yang cukup bagi molekul reaktan akan meningkatkan laju reaksi, sehingga semakin tinggi temperatur konversi molases yang diperoleh akan semakin tinggi pada temperatur yang tidak melebihi temperatur optimum enzim gluko-amilase bekerja. Pada temperatur $90{ }^{\circ} \mathrm{C}$ kadar molases naik dengan pesat hal ini disebabkan tumbukan antar partikel terjadi dengan sering yang menyebabkan enzim bekerja aktif. Unruk tahap sakarifikasi temperatur divariasikan yaitu: $(40-45){ }^{\circ} \mathrm{C},(45-50){ }^{\circ} \mathrm{C},(50-55){ }^{\circ} \mathrm{C},(55-60){ }^{\circ} \mathrm{C}$. Pada tabel 4 terlihat bahwa pada menit ke 196 - 316 kadar molasesnya sudah konstan hal ini disebabkan partikel-partikel tidak memiliki energi yang cukup untuk melakukan tumbukan sehingga tidak menghasilkan suatu reaksi.

\section{Pengaruh temperatur terhadap kadar molases pada proses sakarifikasi}

Pengaruh temperatur terhadap kadar molases pada proses sakarifikasi dengan menggunakan tepung sebanyak 30 gram, massa air sebanyak 300 gram, enzim $\alpha$-amilase $(0,021 \mathrm{~g})$, enzim gluko-amilase $(0,02 \mathrm{~g})$, pada rentang temperatur $(40-45)^{\circ} \mathrm{C},(45-50)^{\circ} \mathrm{C},(50-55)^{\circ} \mathrm{C},(55-60){ }^{\circ} \mathrm{C}$ selama kurang lebih 5 jam

Tabel 5 Data perhitungan hasil hidrolisis selama kurang lebih 5 jam

\begin{tabular}{|c|c|c|c|c|c|}
\hline No & $\mathrm{T}\left({ }^{\circ} \mathrm{C}\right)$ & $\mathrm{t}$ (menit) & kadar molases & massa molases & $\eta(\%)$ \\
\hline 1 & $40-45$ & 316 & 8.8 & 19.33 & 64 \\
\hline 2 & $45-50$ & 310 & 11.6 & 25.69 & 86 \\
\hline 3 & $50-55$ & 303 & 13 & 26.27 & 88 \\
\hline 4 & $55-60$ & 301 & 14.6 & 28.86 & 90 \\
\hline
\end{tabular}

Berdasarkan Tabel 4.5 dibuat diagram sebagai berikut:

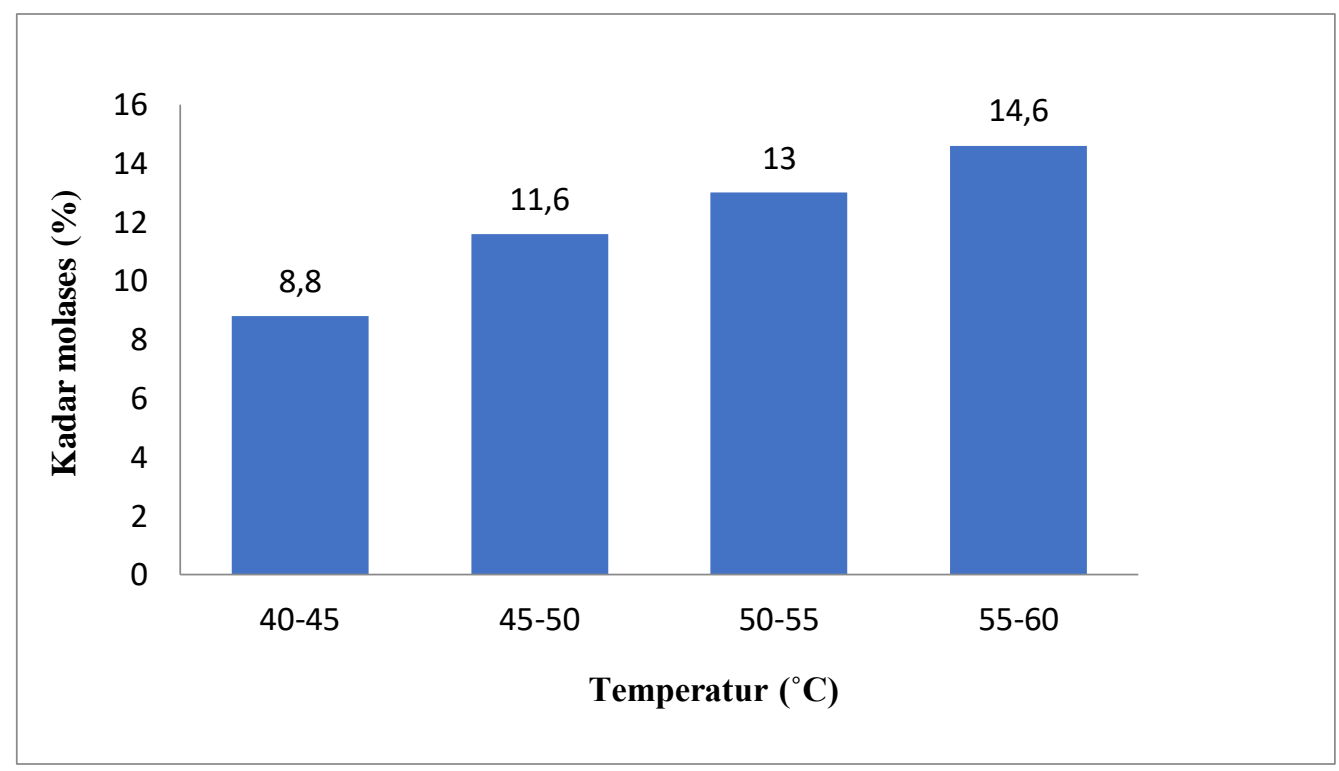

Gambar 1 Pengaruh temperatur terhadap kadar molases pada proses hidrolisis.

Dari gambar 1 dapat dilihat bahwa pada temperatur (40-45) ${ }^{\circ} \mathrm{C}$ kadar molases yang dihasilkan yakni $8,8 \%$ dan pada temperatur $(45-50)^{\circ} \mathrm{C}$ kadar molases yang dihasilkan yakni $11,6 \%$ sedangkan pada temperatur (50-55) ${ }^{\circ} \mathrm{C}$ kadar molases yang dihasilkan meningkat menjadi $13 \%$ dan pada temperatur $(55-60){ }^{\circ} \mathrm{C}$ kadar molases lebih meningkat menjadi 14,6\%. Ini artinya semakin tinggi temperatur maka kadar molases juga akan 
semakin bertambah. Pada temperatur rentang (40-45) ${ }^{\circ} \mathrm{C}$ hanya sebagian kecil molekul yang memiliki energi aktivasi yang cukup untuk bertumbukan menghasilkan reaksi, sehingga tepung jagung yang berhasil terhidrolisis lebih sedikit, sebaliknya pada temperatur (55-60) ${ }^{\circ} \mathrm{C}$ energi kinetik molekul naik sehingga menyebabkan peningkatan laju reaksi. Pada temperatur tersebut adalah temperatur optimum enzim glukoamilase bekerja. Hal ini bersesuaian dengan distribusi Maxwell-Boltzmann yang menyatakan bahwa reaksi akan semakin cepat dengan adanya pertambahan temperatur.

\subsection{Pengaruh Temperatur terhadap massa molases}

Pengaruh temperatur terhadap massa molases pada proses sakarifikasi dengan menggunakan tepung sebanyak 30 gram, massa air sebanyak 300 gram, enzim $\alpha$-amilase $(0,021 \mathrm{~g})$, enzim gluko-amilase $(0,02 \mathrm{~g})$, pada rentang temperatur $(40-45){ }^{\circ} \mathrm{C},(45-50){ }^{\circ} \mathrm{C},(50-55){ }^{\circ} \mathrm{C},(55-60){ }^{\circ} \mathrm{C}$ selama kurang lebih 5 jam.

Tabel 4.7 Data perhitungan hasil hidrolisis selama kurang lebih 5 jam

\begin{tabular}{|c|c|c|c|c|c|}
\hline No & $\mathrm{T}\left({ }^{\circ} \mathrm{C}\right)$ & $\begin{array}{c}\mathrm{t} \\
\text { (menit) }\end{array}$ & kadar molases & massa molases & $\eta(\%)$ \\
\hline 1 & $40-45$ & 316 & 8.8 & 19.33 & 64 \\
\hline 2 & $45-50$ & 310 & 11.6 & 25.69 & 86 \\
\hline 3 & $50-55$ & 303 & 13 & 26.27 & 88 \\
\hline 4 & $55-60$ & 301 & 14.6 & 28.86 & 90 \\
\hline
\end{tabular}

Berdasarkan tabel 4.7 dibuat diagram sebagai berikut:

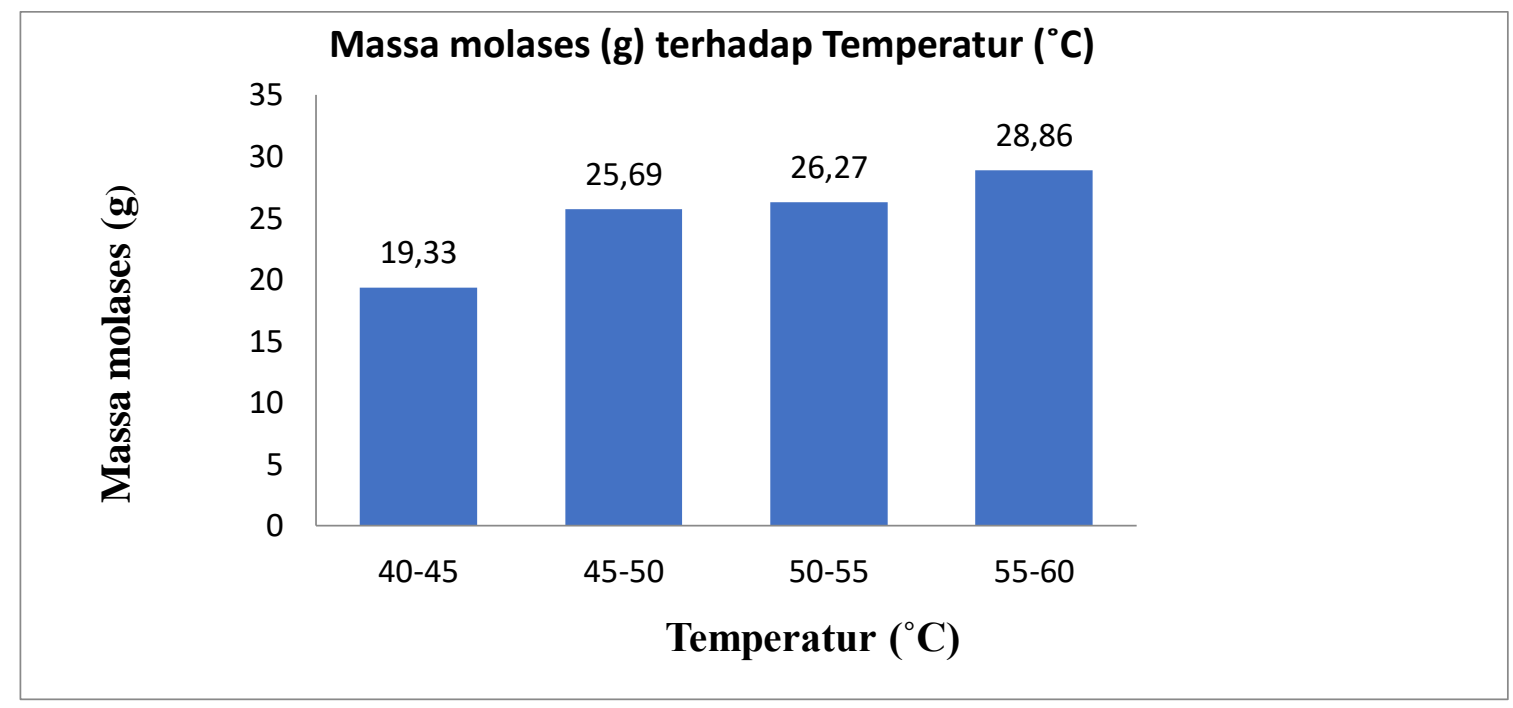

Gambar 2 Pengaruh temperatur terhadap massa molases pada proses hidrolisis.

Dari gambar 2 terlihat bahwa pada temperatur (40-45) ${ }^{\circ} \mathrm{C}$ massa molasses yang terbentuk sebanyak 19,33 gram, hal ini disebabkan karena hanya sebagian kecil molekul yang memiliki energy aktivasi yang cukup untuk meningkatkan laju reaksi, sehingga tepung jagung yang berhasil terhidrolisis lbih sedikit, sedangkan pada temperatur (55-60) ${ }^{\circ} \mathrm{C}$ massa molasses yang terbentuk sebanyak 28,86 gram, hal ini disebabkan karena molekul memiliki energi yang sama dan melebihi energy aktivasi untuk meningkatkan laju reaksi, sehingga tepung jagung yang terhidrolisis lebih banyak. Ini artinya bahwa semakin tinggi temperatur maka semakin banyak tepung jagung yang terhidrolisis menjadi molasses. 
https://jurnal.unsulbar.ac.id/index.php/saintifik

\section{KESIMPULAN}

Dari penelitian yang dilakukan didapatkan nilai kadar molases, massa molases, dan nilai efisiensi. pada temperatur (40-45) ${ }^{\circ} \mathrm{C}$ kadar molases yang dihasilkan yakni 8,8\%, massa molases 19,33 gr, efisiensi $64 \%$. Pada temperatur (45-50) ${ }^{\circ} \mathrm{C}$ kadar molases yang dihasilkan yakni 11,6\%, massa molases $25,69 \mathrm{gr}$, dan efisiensi $86 \%$. Pada temperatur $(50-55)^{\circ} \mathrm{C}$ kadar molases yang dihasilkan meningkat menjadi $13 \%$, massa molases 26,27 gr, dan efisiensi $88 \%$. Pada temperatur (55-60) ${ }^{\circ} \mathrm{C}$ kadar molases lebih meningkat menjadi 14,6 $\%$, massa molases 28,86 gr dan efisiensi $90 \%$.. Ini artinya semakin tinggi temperatur maka kadar molases juga akan semakin bertambah. Pada temperatur rentang (40-45) ${ }^{\circ} \mathrm{C}$ hanya sebagian kecil molekul yang memiliki energi aktivasi yang cukup untuk bertumbukan menghasilkan reaksi, sehingga tepung jagung yang berhasil terhidrolisis lebih sedikit, sebaliknya pada temperatur (55-60) ${ }^{\circ} \mathrm{C}$ energi kinetik molekul naik sehingga menyebabkan peningkatan laju reaksi. Pada temperatur tersebut adalah temperatur optimum enzim gluko amilase bekerja. Hal ini bersesuaian dengan distribusi Maxwell-Boltzmann yang menyatakan bahwa reaksi akan semakin cepat dengan adanya pertambahan temperatur.

\section{DAFTAR PUSTAKA}

Edra, Rabia. 2017. "Pengertian dan Sifat - sifat Enzim", https://blog.ruangguru.com/pengertian-dan-sifat-sifatenzim, diakses pada tanggal 20 Juli 2020 pukul 13.49

G,C, Goncalves. 2016. "Production of bio-oil and activated carbon from sugarcane bagasse and molasses" dalam Biomass and Bioenergy. Department of Chemical Engineering, State University of Maringa, maringa, PR, Brazil.

Gozan, M. 2014. Teknologi Bioetanol Generasi Kedua, Jakarta: PT Gelora Aksara Pratama.

Halliday, D., Resnick. R. 2014. Fisika Dasar Jilid 3. Edisi-7. Erlangga. Jakarta.

Khariyah, A., Suci, FW., Primadani, IPP.,Putra, MID., Emanda, NA., Fadhilah, R., Mihardja, US. 2015. Teori Tumbukan dan Energi Aktivasi. Banten.

Santana, J.O. 2016. Characterization of the legumains encoded by the genome of Theobroma cacao L. Plant physiology and biochemistry : PBB / Sosiete francaise de physiologie vegetale, 98, pp. 162 70.Available at : https://www.sciencedirect.com/science/article/pii/S0981942815301650.

Suripto., Ma'arif, S., Arkeman, A. 2013. Pengembangan Gula Cair Berbahan Ubi Kayu Sebagai Alternatif Gula Kristal dengan Pendekatan Sistem Inovasi. Jurnal Teknik Industri ISSN : 1411-6340. Fakultas Teknologi Pertanian IPB-Bogor.

Wati, W. 2015. Aplikasi Distribusi Maxwell-Boltzman dalam Menetukan Kecepatan Molekuler. Jurnal Ilmiah Pendidikan Fisika AL-Biruni, 3, 63. 